England, the second possibly more rapid than the first. The cooling which we suggest these changes may imply took place over a period of $15 \mathrm{Myr}$. This is of interest in relation to the palaeotemperature curves for the North $\mathrm{Sea}^{3,18}$, which indicate a sudden and rapid cooling at the close of the Eocene. The floristic changes shown in our results from the Palaeogene of southern England suggest that climatic events were more complex than is indicated by the recognition of a single 'terminal Eocene event'.

M.E.C. acknowledges receipt of a NERC research fellowship during the tenure of which part of this work was completed. Results from the Ramnor borehole are published with permission of the director of Institute of Geological Sciences.

Received 7 January; accepted 10 March 1980.

1. Wolfe, J. A. Am. Scient. 66, 694-703 (1978)

2. Wolfe, J. A Palaeogeogr. Palaeoclimatol. Palaeoecol, 30, 313-323 (1980).

Buchardt, B. Nature 275, 121-123 (1978)

Savin, S. M. A. Rev. Earth planet. Sci. 5, 319-355 (1977)

Gruas-Cavagnetto, C. Mém. Soc. géol. Fr. 131, 1-64 (1978)

. Cavelier, C. Sci. géol. (Strasbourg) Mém. 54, 1-280 (1979).

. Chateauneuf, J-J. Mém. Bur. Rech. géol. Minièr. 116, 1-360 (1980)

8llivier-Pierre, M-F. Mém. Soc. géol. minér. Bretagne 25, 1-239 (1980).

9. Fowler, K. in 5th int. Palyn. Conf., Cambridge (1980).

10. Curry, D. et al. Geol. Soc. Lond. spec. Rep. 12, 1-72 (1978).

11. I. G. S, boreholes 1977. Rep. Inst. geol. Sci. No. 78/21 (1978).

12. Collinson, M. E. thesis, Univ. London (1978)

13. Fisher, O. Q. Jl geol. Soc. Lond. 18, 65-94 (1862).

14. Chateauneuf, J. J. Bull. B.R.G.M.Sect.IV, Géol. Générale. Suppl. Serv. Géol. Nat. RS 812 (1979).

15. Haseldonckx, P. Geol. Mijnb. 51, 645-650 (1972)

16. Fowler, K. Pollen Spores 13, 135-147 (1971).

17. Fowler, K., Edwards, N. \& Brett, D. Palaeontology 16, 205-217 (1973).

18. Buchardt, B. Dansk. Met. Inst. Climatol. Pap. 4, 243-248 (1978)

19. Hardenbol, J. \& Berggren, W. A. A.A.P.G. Stud. Geol. 6, 213-234 (1978)

20. Hooker, J. J., Insole, A. N., Moody, R. T. J., Walker, C. A. \& Ward, D. J. Tert. Res. 3, 1-45 (1980).

21. Chandler, M. E. J. The Lower Tertiary Floras of Southern England Vol. 4 (British Museum Natural History, London, 1964)

22. Collinson, M. E. Ann. Bot. 46, 603-632 (1980)

23. Chandler, M. E. J. Bull. Br. Mus. nat. Hist. geol. 5, 13-41 (1961).

24. Crane, P. R. Tert. Res. 1, 95-99 (1977).

25. Chandler, M. E. J. The Lower Tertiary Floras of Southern England Vol. 2 (British Museum Natural History, London, 1962).

\section{A new assessment of Rhyniella, the earliest known insect, from the Devonian of Rhynie, Scotland}

\section{Paul Whalley \& E. A. Jarzembowski}

British Museum (Natural History), Department of Entomology, Cromwell Rd, London SW7 5BD, UK

The search for insects (Class Hexapoda) in rocks of Devonian and Lower Carboniferous age (325-415 Myr BP) has continued for many years because so little is known of the early history of these diverse and abundant animals. In 1926, four head capsules of an insect, named Rhyniella praecursor, were discovered in Lower Devonian chert from Rhynie, Aberdeenshire ${ }^{1}$ by examining thin fragments of this chert, which are rather translucent, like amber. Subsequently, about 10 additional specimens were found showing the legs and thorax of this insect ${ }^{2}$. It has become generally accepted that $\boldsymbol{R}$. praecursor belongs to the living Order Collembola or springtails, a widespread, flightless group of insects. However, several characters of Collembola were not preserved in the fossils and doubts remained. Furthermore, the apparent similarity of Rhyniella to some specialized modern Collembola ${ }^{3}$ has suggested that Rhyniella was a modern contaminant ${ }^{4}$. Our research shows that Rhyniella is not a contaminant; we have also found the first intact abdomen of Rhyniella which has a special locomotory appendage similar to that of modern Collembola.

We initially decided to search the Rhynie Chert because it is the only formation before the Upper Carboniferous to have yielded insect remains. The samples we examined were excavated during the International Botanical Congress in 1964 by J. Pettitt and C. Shute of the Department of Palaeontology,

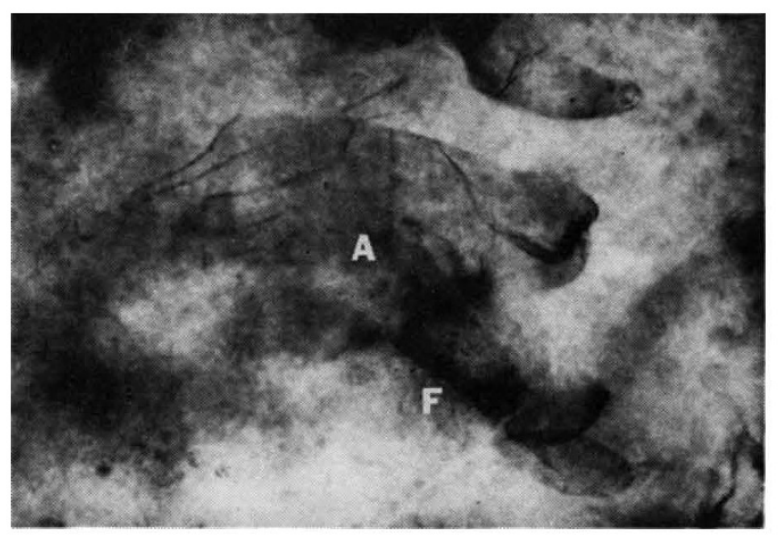

Fig. 1 Photograph of $R$. praecursor, fossilized in chert from Rhynie. A, abdomen; F, furcula.

British Museum (Natural History). However, no insects were found although several arachnids were discovered. We then re-examined the original material collected over $50 \mathrm{yr}$ ago; in a few cases the chert was thick and thus was ground and repolished to see the contents more clearly. As a result, a new specimen was revealed which consists of a thorax with legs and the firstdiscovered complete abdomen. Extending from the ventral surface of the abdomen is a structure corresponding to the furcula ('spring') of Recent Collembola (Figs 1,2). Only the hind end of the Rhyniella abdomen can be seen in Fig. 1 because the body is oblique to the plane of view. The presence of a furcula confirms that Rhyniella was a springtail; the total length of the insect was $\sim 1.5 \mathrm{~mm}$. Figure 2 shows a Recent springtail which has a slender apex (dentes) to the furcula.

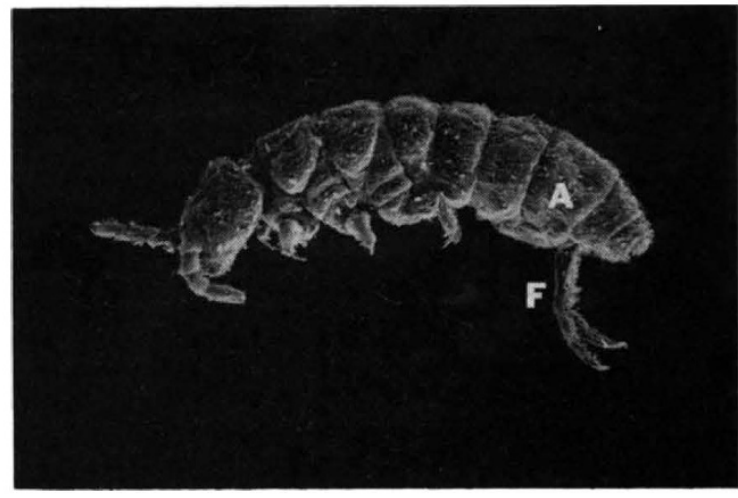

Fig. 2 A Recent springtail. A, abdomen; F, furcula.

Examination of several specimens of Rhyniella showed that they were completely fossilized in chert and did not look like modern contaminants. They were examined petrologically in polarized light by A. R. Woolley and the enclosing chert was found to be homogeneous and certainly represented a single phase of mineral growth. One Rhyniella specimen was associated with a plant fragment in homogeneous chert and J. B. Richardson confirmed that the petrification of this was identical to other Rhynie plants of undoubtedly Devonian age. We conclude that Rhyniella praecursor is of Lower Devonian age (possibly Siegenian).

Thus Collembola were established and already developing their specialized mode of locomotion some $380 \mathrm{Myr}$ ago. The relationship of Rhyniella with Recent Collembola Neanuridae is doubtful and a fuller account will be published elsewhere.

We thank P. N. Lawrence for advice on Collembola.

Received 24 November 1980; accepted 30 March 1981.

1. Hirst, S. \& Maulik, S. Geol. Mag. 63, 69-71 (1926)

2. Scourfield, D. J. Nature 145, 799-804 (1940).

3. Massoud, Z. Revue Ecol. Biol. Sol. 4(3), 497-505 (1967).

4. Crowson, R. A. Classification and Biology, 1-350 (Heinemann, London, 1970). 